\title{
Balancing the Frame of Threat: Uninvited Migrants in the
}

\section{Finnish News}

\section{Horsti, Karina}

Unipub

2010

Horsti , K 2010 , ' Balancing the Frame of Threat : Uninvited Migrants in the Finnish News ', in K Skare Orgeret \& A H Simonsen (eds), Elisabeth Eide . det utålmodige mennesket ., Unipub, Oslo, pp. 91-109.

http://hdl.handle.net/10138/24060

Downloaded from Helda, University of Helsinki institutional repository.

This is an electronic reprint of the original article.

This reprint may differ from the original in pagination and typographic detail.

Please cite the original version. 
Rune Ottosen

Ottosen, R. (2010) The War in Afghanistan and Peace Journalism in Practice in War and the Media (under utgivelse)

Rossland, I. E. (2006) Den norske militær godteposen. En analyse av Aftenpsotens dekning av Norges deltagels i krigen i Afghanistan. Hovedfagsrapport 2006 nr. 10. Høgskolen i Oslo. 


\title{
Balancing the Frame of Threat: uninvited migrants in the Finnish news
}

\author{
Karina Horsti, University of Helsinki
}

In December 2009, a twenty-seven year old Finnish man died of an overdose at a luxury hotel in Helsinki. He had taken heroine thinking it was cocaine. It was soon revealed that the drugs had been smuggled and distributed by Nigerian, Gambian and Ghanaian migrants. Although this event is exceptional, it fits into a long-running narrative depicting (some) foreigners as social threats.

Of course, a young man's death has nothing to do with Afghan asylum seekers smuggled by Russians into Finland, or with Nigerian prostitutes arriving in Finland on Italian permits. Nevertheless, all three stories were published as one news package on the same page in the Finnish national daily, Helsingin Sanomat (February 12, 2010). The story of the drug victim catches the reader's attention and creates proximity to the topic of "crime by foreigners». The main headline unambiguously framed immigration as a threat:

Illegal entries to the country explode. In January-February more than 5000 resided illegally. A criminal gang brought Afghans from 
Karina Horsti

Russia and were paid thousands of euros. (Helsingin Sanomat, February 12, 2010)

The two other headlines underlined the theme of «crime by foreigners»:

"Tens of foreigners distributed hard drugs," and "Travel costs of prostitutes were paid with stolen credit card information.»

These examples demonstrate how the choice of the words «explode» and «illegal» promotes an understanding of immigration as a threat. On this page of the newspaper, several problems were presented as originating from migration and migrants. The newspaper used a domestic framework presenting Finnish and European societies as victims of a foreign and often criminal non-European «invasion». The role of the host countries in this kind of mobility was not discussed. Issues such as increased border and immigration control, the markets for prostitution and drugs and unequal social conditions are not mentioned as a context in these short news items.

The spread is a textbook example of routine news coverage framing "uninvited» migrants as a threat. "Crime by foreigners» is the theme linking the individual news items. However, although «uninvited» migrants, such as asylum seekers and undocumented arrivals, are quite frequently represented as crime and problems, particularly in routine news stories (Horsti 2007), European scholars have demonstrated that journalism also tends to frame migrants as victims of war, natural catastrophes or cultural problems in particular nations (Brune 2004, Horsti 2008 a\&b, Gross et al 2007, van Gorp 2005). Above all, women and children are frequently regarded as vulnerable, and their claims for protection are often considered more understandable. 
Recently for instance, the Finnish media have printed stories about individual female asylum seekers threatened by «their patriarchal cultures» as well as by deportation by the Finnish authorities. In these stories, the women are victimized and the borders of the nation state mark the difference between safety and danger. However, unlike foreigners framed as a threat, these individuals are not considered a problem, but are invited to join the national «us» - in safety, but as victims.

In this chapter I shall discuss Finnish news journalism concerning asylum seekers and undocumented migration. ${ }^{1}$ I focus on «the variety of others", a topic Elisabeth Eide has theorized in her work (Eide 2002, 2003). She argues that the media not only construct a division between «us» and «them», but also create varieties of "others", such as the adaptive hero other, the villain other, the dialogic other, the silent/silenced other and the victim other.

The solution to the problems related to otherness is not, however, to recognize that we are all different, as the currently popular discourse that celebrates "cultural diversity» ${ }^{3}$ often claims

\footnotetext{
${ }^{1}$ The arguments are based on the empirical analyses of the news coverage of asylum seekers and undocumented migrants which I have conducted between 1999 and 2010 (reported for instance in Horsti $2003,2007,2008$ a \& b, 2010). The aim here is to bring these studies together and discuss the results from a new perspective.

2 This idea appears in slightly different ways in her work, depending on the context. For instance, in Eide (2003) she makes a distinction in feature stories between the following framings: the other as colourful, as a resource, as a problem, as a victim and as enlightening. In addition, she identifies the frame of «we as a problem».

${ }^{3}$ For instance, the European Commission lumps together issues of gender, disability, race/ethnicity under an «all different all equal» banner in its campaign. (See e.g. http://europa.eu/youth/your_rights/all_different,_all_equal/index_eu_en.html). More analysis of the discursive shift from multiculturalism to cultural diversity in Horsti (forthcoming).
} 
Karina Horsti

(Horsti, forthcoming). Sara Ahmed (2000:6) is one of the scholars to warn that such generalizations could lead to not «dealing with the political processes whereby some others are designated as stranger than other others».

In this chapter I discuss the frames of «threat» and «victim» which are typical of the media's coverage of asylum seekers and undocumented migrants. In Eide's terms, I focus on how news journalism frames uninvited migrants as «the victim other» and «the villain» or «the problem other». How are these two categories of otherness related? If migrants are represented as victims, does that balance the news stories representing them as a threat?

My understanding of the concept of media frames is similar to Todd Gitlin's classic quote:

Frames are principles of selection, emphasis, and presentation composed of little tacit theories about what exists, what happens, and what matters. (...) Media frames, largely unspoken and unacknowledged, organize the word both for journalists who report it and, in some important degree, for us who rely on their reports. (Gitlin 1980:6-7.)

It is important to note that the concept of «media frame» is not synonymous with a journalistic perspective which is consciously decided and selected. «Media frame» refers to a more unconscious process producing an understanding of an event or phenomenon. Framing results from selection which is often more or less unacknowledged. For instance, it involves journalistic practices, the pre-understanding of the journalist and sources and cultural preferences.

In the analysis I shall attend to the two devices identified in Robert Entman's (1993) theorization of frame analysis: the reasoning device and the framing device. The reasoning device 
refers to the narrative structure produced in a single news story and in a sequence of news stories about a particular topic. To identify the narrative, I have analyzed what is defined as problems and what is offered as the causes of and solutions to these. In addition to the development of a narrative, I have analyzed the words and sentences, i.e. the framing device. This level of analysis helps analyze the narrative level.

\section{Divisions: migrants as threats}

In countries such as Finland where migrant communities are rather small, the variety of possible sources relating to undocumented migration and asylum seeking is rather narrow. Human rights organizations or religious communities often speak on behalf of the migrants, but must be considered sources with their own agendas. In Finland, minorities are not (yet) organized in ways providing routine, everyday sources for journalists.

Border control officials, the police and other immigration authorities are typical sources of news about asylum seekers and undocumented migrants (Raittila and Vehmas 2005). From their perspective, this type of uninvited migration is a problem that needs solving. Asylum seekers need to be housed, their entry needs require investigation, their smugglers need to be caught, their applications examined, their legal claims settled in court, and finally those who are not accepted need to be deported. The migrants are treated as strangers who threaten public law and order and the morals and health of the nation they have entered. Typically, the news media use metaphors based on nature, thereby dissipating the political, economic and social dynamics that generate migration, to describe the migrants' movement. Asylum seekers and undocumented migrants "flood", «flow into» or arrive like an «avalanche» in Finland. 
This non-personified language is not only typical in stories which frame immigration as a threat; it may also appear in stories framing immigrants as victims. In 1999, Helsingin Sanomat (May 1, 1999) printed such a story, while treating the migrants as non-personified goods: "Just after Mother's day the next set arrives, about 500 Kosovo Albanian refugees.»

The story treats Kosovo Albanians as victims of war and as entitled to refugee status. Still, the word «set $»^{4}$ refers to a quantity of goods rather than human beings. Another more recent example in Helsingin Sanomat (March 19, 2010) rather untypically presents unwanted mobility as a global issue, not just a Finnish or European one. The article reports about refugees arriving in Yemen from neighbouring countries. Individual suffering is highlighted and the story rouses the compassion of readers with the victims of war and violence. The headline, however, follows the typical pattern of non-personified language: «Poor refugees flood into Yemen».

Thus, whether migrants are treated as threats or as victims, their position is characterized to that of a non-personified object.

The entry and existence of asylum seekers and undocumented migrants are often described as «illegal». The adjective «illegal» may precede almost any noun. Irrespective of international agreements, migrants can be characterized as «illegal refugees», «illegal migrants» or «illegal arrivals» in the press (Horsti 2007, 2008 b). Thereby, illegality becomes self-explanatory and its use goes unchallenged. Journalists often fail to acknowledge that people who flee unstable conditions are not necessarily able to obtain the documents required by Europe's increasingly tighter border control.

Routine news journalism seldom explains why asylum seekers arrive. The narrative perspective is national or European. For instance, news about climate change is rarely linked to African

\footnotetext{
${ }^{4}$ Erä in Finnish.
} 
migration to Europe, although many of the difficulties individual migrants face stem from this. Moreover, national framing tends to ignore unwanted mobility as a global crisis: the majority of the world's displaced people remain in the neighbouring countries of Asia and Africa. The story about the refugees in Yemen was exceptional in this sense. However, the story was published in the foreign news section, clearly separate from the domestic section in which issues related to asylum seeking are usually discussed.

\section{Divided refugee policy}

The fall of Communism in the late 1980s changed the way in which asylum seekers were perceived in Europe. In Finland, however, the issue first entered public discussion in the early 1990s when the first Somali asylum seekers arrived via the Russian border. Ever since, asylum seeking has been linked with suspected hoaxes, crime and disease. The negative connotations of the word «asylum seeker» became manifest in the 1990s and humanitarian aspects were often neglected. In everyday language, two categories emerged: «the genuine refugee» (victim) and «the bogus asylum seeker» (threat).

In addition to the mediated debate, we also have to consider divisions within the refugee policy itself. In Finland, like in the other Nordic countries, there is an administrative distinction drawn between quota refugees ${ }^{5}$ (UNHCR resettlement pro-

\footnotetext{
${ }^{5}$ There are about twenty to twenty-five countries which select quota refugees, Finland has been among them since 1979. The quota is defined annually by the government. Since 2001, the quota has been 750 persons, but in practice Finland usually accepts fewer number of refugees. In February 2010 the minister for development issues publicly declared that he wanted to decrease the quota. (Finnish Immigration Service website www.migri.fi. Referred 23 February 2010.)
} 
gramme) and asylum seekers. Finnish authorities annually select 750 refugees for «resettlement» from UNHCR refugee camps. A genuine need for international protection is the main criteria for protection. Women, children and the elderly are mentioned as particularly vulnerable, and victims of torture and people needing medical care are considered special groups. In addition, although not as explicitly defined, «integration potential» has become a decisive factor in the selection process (Garnier 2009: $8-9)$. The refugee preferred is not only vulnerable, but also adaptable and suited to «our» society. In Finland for instance, the quota often remains unfilled as suitable refugees cannot be found. As a newspaper report based on an interview with a Ministry of the Interior official explains: «Predictable difficulties in integration might prevent one's selection [for the quota].» (Helsingin Sanomat February 24, 2010.)

Moreover, in his arguments against expanding the quota, another politician underlined integration difficulties: «This is a decent number because even now we have had problems with integration». (Helsingin Sanomat February 24, 2010.)

Unlike the selectively managed quota immigrants, asylum seekers enter the country spontaneously by whichever route they are able to find to pass the increasingly tough border controls. Once inside, the quota migrants slip into the victim frame more easily than the asylum seekers. They are more easily designated as genuine victims who passively and gratefully adapt to society. The asylum seekers are different: by definition, they are active agents with claims for recognition and resources. Still, in the news they are often treated either as passive objects by the authorities who file their claims, monitor, move and sometimes deport them - or as negatively active agents causing disorder. 
Balancing the Frame of Threat: uninvited migrants in the Finnish news

\section{Migrants as victims: transition from "the other" to "Us")}

The dualistic representation of asylum seekers and undocumented migrants as «genuine» versus «bogus asylum shoppers» dates from the 1990s. For instance, in spring 1999 the prime minister at the time, Paavo Lipponen, was heavily criticized for announcing that Finland would accept only fifty refugees from UN camps in Kosovo. The news coverage framed them as victims, and finally, after a public debate, Finland accepted 1000 refugees. On May 1, 1999, Helsingin Sanomat published the headline: «The good news of this week: now the Finns want to help».

Why were the Finns so eager to help Albanian refugees from Kosovo? The news images reminded many of the Karelian evacuees who left their territories in the war between Finland and the Soviet Union in 1939 - 1944. Helsingin Sanomat explicitly domesticated the refugees' experiences by constructing an emotional and historical parallel between Kosovo and the Karelian evacuees by using the following headline: «Kosovo elicits memories of Karelia». (Helsingin Sanomat May 1, 1999.) This theme was followed up in the article:

[...] television began to show images in which the elderly were led into muddy fields and children cried for their lost parents. The destiny of the Kosovo Albanians has evoked the Karelians' own war memories. [...] Now images of the Albanians activate their memories. They remember how it felt. Neither the Karelian children from those days nor the children of Kosovo could understand why they had to dress quickly and leave for the unknown. (Helsingin Sanomat May 1, 1999.) 
Later that year, Slovakian Roma arrived in Finland as asylum seekers (Slovakia was not an EU member at the time). The Roma were swiftly framed as «unfounded» asylum seekers. They were presented as a problem, seemingly «flooding» and «flowing» into the country in an endless stream. Soon the news media began to look for solutions. Politicians and immigration authorities were under public pressure. Something needed to be done quickly: the «spontaneous» Roma «flow» had to be stopped. The government introduced visa regulations for Slovakian citizens, and the Roma stopped coming. The problem seemed solved, and the news coverage ceased (Horsti 2003).

Discrimination of the Roma in Eastern Europe was discussed in stories by Finnish journalists reporting from Slovakia and published in the foreign news pages. The domestic news concentrated only on the authorities and the domestic administrative problems caused by the arrival of the Roma. After Romania (2007), Bulgaria (2007) and Slovakia (2004) joined the EU, the Roma issue re-emerged in the public debate, particularly during summertime. The debate now focused on the Roma beggars and the threat to morals and hygiene which they posed. This time, no visa control would stop the flow since these people were arriving from an EU member state.

Activists who campaign for the rights of immigrants and asylum seekers often consider the threat and victim frames differently and even oppositely. For instance, a toolkit - «Information about Refugees for Journalists» - stresses that journalists need to know facts and become more sensitive to language use. The following quote is an example of an attempt to re-frame asylum seekers as victims instead of a threat. "Asylum seekers are victims of terrorism and war on terror rather than tools for terrorism» (Information about Refugees for Journalists 2006). 
However, a crucial question which needs addressing is agency: why are some migrants framed as victims and others as threats?

Some human rights organizations acknowledge the political pressure on the asylum system in Europe today and thus have to maintain the categories and distinctions between «approved» refugees and those not entitled to protection. For instance, UNHCR is not keen on publicly criticizing asylum decisions. The organization operates in an environment of shifting policies, and is after all largely funded by governments. The UNHCR chooses to protect the asylum system itself by avoiding public involvement in asylum decisions. ${ }^{6}$

The approved migrant is moved from «the other» category to «us». In his writing on distant suffering, the French philosopher Luc Boltanski (1999:11) argues that although humanitarian action is ideally considered to be universalistic, a familiar "communitarian figure» often appears. A suitable victim is someone who has been defined to qualify as a victim, and potentially one of «us», at least to such a degree that he/she can be protected.

I am interested in the ways this familiar figure is constructed in media representations. Representation is always selection: some features are selected and underlined, while others remain in the background. The victim frame is rather recent in Finnish news coverage of asylum seekers and migrants, particularly in the hard news genre. For instance, in 2002 the Finnish news agency STT did not frame asylum seekers as victims at all (Horsti 2007).

For instance a number of organizations, such as the Refugee Council, Amnesty International and the No Border network, succeeded in raising a nationwide debate about how asylum

\footnotetext{
${ }^{6}$ Hanne Marie Mathisen, Senior Regional External Relations Officer, Regional office for the Baltic and Nordic countries. UNHCR. Interview by Karina Horsti June 3, 2009.
}

$$
-101-
$$


seekers were treated in 2007. The Evangelical Lutheran Church campaigned with these organizations against the deportation of three female asylum seekers. All three women were presented as victims of their "own culture» and of the heartless Finnish asylum policy.

The Evangelical Lutheran Church was involved in making the asylum issue relevant and challenging the authority of the Directorate of Immigration. In 2007, the Ecumenical Council of Finland published a guidebook for parishes entitled «The Church as an Asylum»; ; soon after, three separate parishes publicly offered shelter to asylum seekers threatened with deportation. The involvement of the Church and collaboration with NGOs and activist groups were strategies that had been used in some other European countries since the 1980s. The Norwegian and Swedish Christian communities in particular have provided examples to the Finnish activists. It was the involvement of a, by quite a few citizens, respected authority, the Evangelical Lutheran Church, which increased the seriousness of this pro-immigration activism. Finally, news journalism framed the issue as a dispute between two institutions - the Directorate of Immigration and the Evangelical Lutheran Church - and this actually drew attention away from asylum seekers per se to institutional battles.

However, in the end, the Church and the activist groups considered their joint public campaign successful. All three women received temporary residence permits and were not deported.

The three women - Naze Aghai from Iran, Irina Lyukhatan from Russia and Anna Lado from Sudan - were framed as victims of their cultures as well as of the Finnish policy. Following

\footnotetext{
7 The proper English translation would be «the Church as Shelter", but I wish to underline that the guidelines use the same noun "turvapaikka» as is used in the legal term "asylum».
} 
Boltanski's idea of a "communitarian figure», why them and not others?

First, they were all women. There have not been similar campaigns for any male asylum seeker in Finland. Second, the women were presented as integrated with Finnish values. Ms Aghai's public image was de-muslimized and de-ethnicized. She was photographed in a church, under the cross, with priests, and no sign of any «ethnic difference». She was dressed in jeans and a t-shirt.

Islam and Muslims were represented as patriarchal. Finnish values and society were symbolically purified in comparison with the «suppressive otherness». In Finland, the two other women were photographed in motherly roles with children, thus aiding the transition from the category of «the other» to the realm of "us». A similar discursive move has been demonstrated in the public debate about the Fadime Sahindal case in Sweden (see e.g. Simonsen 2004). The Swedish media narrated events around the murder of Fadime Sahindal within the familiar framework of the "Romeo and Juliet» story which de-ethnicized the young couple. Ms Sahindal was killed by her family members, and Muslim culture was presented through the lens of «honour killing». Swedish society and culture, however, were presented as non-violent, safe and equal.

The news coverage and public debate got stuck in a rhetorical traffic jam where particularly the two influential institutions - the Church and the Directorate of Immigration - drew all the attention. A discursive gridlock (Hasinoff 2008) prevented any structural debate and criticism of the asylum system. In the end, it was enough for the activists, the Church and the public debate that the three women were saved. No further structural changes ensued. 


\section{Control as a response to illegality and suffering}

Public victimization of some individual migrants might help in individual cases, but it may not necessarily have any significant impact on immigration policy. It is possible to recognize individual suffering and the need for protection while favouring increased immigration control. For instance, the cause of «genuine refugees» is sometimes supported with criticism of "queue jumping» and «bogus asylum seeking».

We can find a similar duality in the argument related to the recent mediated and Europeanized «migration crisis» in the Mediterranean and the Canary Islands. On the one hand, news reports about African migrants arriving in rickety boats constructs a public spectacle of suffering, and underlines the humanitarian aspect of the event. On the other hand, African migrants, and particularly their smugglers, are commonly represented as a threat and defined as representing an «illegal migration crisis».

The public solution to both problems - crime and suffering - is migration control. As an example, the European border control agency Frontex argues that expensive control and patrol operations are needed in the Mediterranean and on the West African coast to prevent humanitarian crises. In its public report, Frontex justifies its operations with humanitarian arguments:

«Total Intercepted in African Coast and diverted during HERA II Operational Phase -3887 illegal immigrants (57 cayucos or pateras) till 15/12/2006. (...)

This means that these people were stopped from setting off for a dangerous journey that might have cost their lives.»

(Hera statistics retrieved 18 August 2008 from http://www.frontex. europa.eu/gfx/frontex/files/hera-statistics.pdf) 
Balancing the Frame of Threat: uninvited migrants in the Finnish news

Similarly, in the following excerpt from Helsingin Sanomat (June 1, 2006), EU patrol operations are justified with human rights arguments presented by the EU commission:

The European Union is going to build a patrol network to the Mediterranean and Canary Islands areas in order to cut off the flow of illegal migration. An operation in the waters off the Canary Islands and Malta has been agreed upon. In November, led by Greece, a new joint project to increase the patrolling of the Eastern Mediterranean will be launched. In addition the area's satellite systems will be increased with EU support.

Approximately 50,000 people are desperately looking forward to crossing the sea in Mauritania. There are 25,000 migrants gathered in Senegal who will attempt to cross the sea. Every day people drown. «This tragedy can no longer be accepted», emphasized Franco Frattini, the Vice-President of the EU commission, in an interview with the STT. (Helsingin Sanomat, June 11, 2006.)

Mr Frattini justifies the patrol network and satellite systems with humanitarian arguments, that the tragedy cannot be accepted. Similarly, Frontex praises and justifies its operations with saved lives. This «humanitarian position» gets stuck in the immediate tragedy, the deaths in European waters and on European soil. It ignores the social, economic and political problems which make migrants leave their locations and make such a dangerous journey. News coverage that uncritically supports these justifications ends up legitimizing the border control policies and division between Africa and Europe. 


\section{Discussion: threat and victims as two frames}

I would like to return to the news stories I discussed at the beginning: the three stories of "crime by foreigners" in Helsingin Sanomat. The entire page was clearly written within the frame of immigration as a threat. However, on that page, a victim frame also appears.

At the end of the main article, a police official stresses the following in an indirect quote: "the intention in intensified investigation [of human smuggling and illegal entry] is not to prevent people from entering the country». "The task is to identify those who profit from people's distress or need to come here».

This quote is a reminder that the real criminals are the smugglers who profit from the migrants' hardships. The migrants are the smugglers' victims. This distinction might, however, not be obvious to a reader as the origin of the "problem» is presented as the migrants themselves: their violation of the border, their cost to the society, their physical reminder of the inequalities of the world we live in.

The problems identified are presented in the following order: first, the «illegal» entry and violation of the border; second, the smugglers' exploitation of the migrants. The only source quoted in the article is the police, offering only increased control and «intensified investigation» as solutions to the situation. Thus the same recipe seems to solve the two problems, similar to the humanitarian argument in the case of European patrol and surveillance operation against the African migrants.

Throughout this chapter I have tried to demonstrate that victim framing - an approach often used by anti-racist and pro-immigration activists - is not necessarily strong enough to counter the frame of immigrants as a threat. Victim framing does not neutralize the threat frame; instead it can be used as a 
Balancing the Frame of Threat: uninvited migrants in the Finnish news

complementary frame to legitimize migration control. The same story or a sequence of stories about an event can both identify the individual suffering of migrants and present their arrival and existence as a threat to society.

\section{Literature:}

Ahmed, S. (2000) Strange Encounters. Embodied others in post-coloniality. London: Routledge.

Boltanski, L. (1999) Distant Suffering. Morality, media and politics. Cambridge: Cambridge University Press.

Brune, Y. (2004) Nyheter från gränsen. Tre studier i journalistik om «invandrare», flyktingar och rasistiskt våld. Gothenburg: JMG. Institutionen för journalistik och masskommunikation. University of Gothenburg.

Eide, E. (2003) The Long Distance Runner and Discourses on 'Europe's Others'. Ethnic Minority Representation in Norwegian Feature Stories. In: Tufte, Thomas (ed.). Medierne, minoriteterne og det multikulturelle samfund: skandinaviske prespektiver. Göteborg: Göteborgs universitet.

Eide, E. (2002) «Down there» and «up here»: «Europe's Others» in Norwegian feature stories. Oslo: Universitetet i Oslo.

Entman, R. (1993) Framing: Toward clarification of a fractured paradigm, Journal of Communication 43(4): 51-8.

Garnier, A. (2010) Die Logik der Selektion. Einwanderungsund Flüchtingspolitiks in Europa und Australien. WeltTrends - Zeitschrift für internationale Politik, 71, (18)März/April 2010, pp. 67-75.

Gitlin, T. (1980) The Whole World Is Watching. Berkeley: University of California Press.

$$
-107-
$$


Gorp, B. van (2005) Where is the Frame? Victims and Intruders in the Belgian Press Coverage of the Asylum Issue. European Journal of Communication 20(4): 484-507.

Gross B., Moore K. \& Threadgold, T. (2007) Broadcast News Coverage of Asylum April to October 2006: Caught Between Human Rights and Public Safety. Cardiff: Cardiff School of Journalism, Media and Cultural Studies, Cardiff University.

Hasinoff, A. (2008) Between racism and rape: Discursive gridlock in dominant and marginal newspaper coverage of the Marcus Dixon trial. Paper at ICA conference, Montréal May 22-26, 2008.

Horsti, K. (forthcoming) From multiculturalism to diversity discourse: Anti-racist discourses within European public service broadcasting. In Mark Da Costa Alleyne (ed.) International Antiracist Campaigning: Critical Contradictions. (In-press, Transaction, Rutgers University.)

Horsti, K. (2010) De-ethnicized victims: mediatized advocacy for asylum seekers in Finland. Unpublished manuscript.

Horsti, K. (2008a) Hope and Despair: Representations of Europe and Africa in Finnish news coverage of 'migration crisis'. Communication studies Estudos em Comunicação. 2(1):125-156. Special issue «Issues in international journalism» (ed.) John E. Richardson. http://www.labcom.ubi.pt/ec/03/

Horsti, K. (2008b) Europeanisation of public debate. Swedish and Finnish news on African migration to Spain. Javnost - The Public 15(4): 41-54.

Horsti, K. (2007) Asylum seekers in the news: Frames of illegality and control. Observatorio Journal 1(1): 
Balancing the Frame of Threat: uninvited migrants in the Finnish news

145-161. http://obs.obercom.pt/index.php/obs/article/ view/45/66

Information about refugees for journalists - guidebook

(Pakolaistietoa toimittajille), Finnish Refugee Council, Refugee Advice Center, Red Cross, Amnesty, Finnish Journalist Union, 2006.

Raittila, P. \& Vehmas, S. (2005) Etnisyys ja rasismi sanomalehdissä 1999-2004 - seurantatutkimusten yhteenvetoa ja arviointia. Pp. 11-32. In Pentti Raittila (ed.) Etnisyyttä, rasismia ja dialogia sanomalehdissä ja Internetissä. Tampere: Dept. of Journalism and Mass Communication Studies, University of Tampere.

Simonsen, A. H. (2004) Fadime. Ett drap - to historier. Tabloide nyhetsjegere på rett spor? In Elisabeth Eide \& Anne Hege Simonsen (eds) Å se verden fra et annet sted. Medier, norskhet og fremmedhet. Oslo: Cappelens Forlag. 